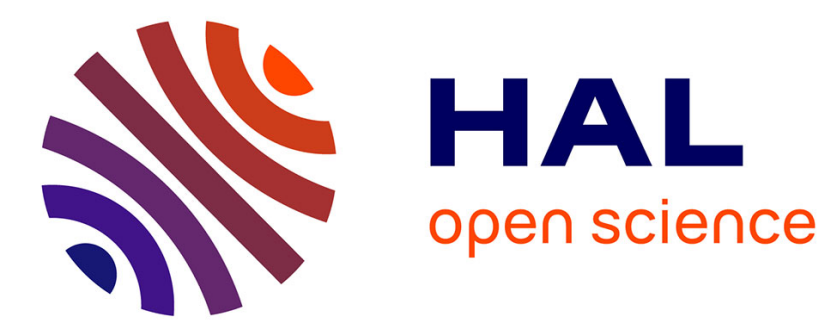

\title{
THE BEHAVIOUR OF OXYGEN ON Ni(110) INVESTIGATED BY ELLIPSOMETRY AND AES
}

L. Hanekamp, A. van Silfhout

\section{To cite this version:}

L. Hanekamp, A. van Silfhout. THE BEHAVIOUR OF OXYGEN ON Ni(110) INVESTIGATED BY ELLIPSOMETRY AND AES. Journal de Physique Colloques, 1983, 44 (C10), pp.C10-469-C10-472. 10.1051/jphyscol:19831093 . jpa-00223551

\section{HAL Id: jpa-00223551 https://hal.science/jpa-00223551}

Submitted on 1 Jan 1983

HAL is a multi-disciplinary open access archive for the deposit and dissemination of scientific research documents, whether they are published or not. The documents may come from teaching and research institutions in France or abroad, or from public or private research centers.
L'archive ouverte pluridisciplinaire HAL, est destinée au dépôt et à la diffusion de documents scientifiques de niveau recherche, publiés ou non, émanant des établissements d'enseignement et de recherche français ou étrangers, des laboratoires publics ou privés. 
Department of Applied Physics, Twente University of Technology, P. 0 . Box 217, $7500 \mathrm{AE}$ Enschede, The Netherlands

Rêsumé - L'effet sur les paramètres ellipsométriques de l'exposition d'une surface Nì (110) à T'oxygène a été trouvê indépendant de la modification de la surface qui se produit spontanément après bombardement ionique. Un nodèle est suggéré selon lequel 1a modification observée de la surface est expliquée par désorption et diffusion d'argon et d'oxygène, respectivement. La concentration d'oxygène dans la couche superficielle a été dēterminée à l'aide de calculs sur des modèles.

Abstract - The effect on the ellipsometric parameters of a $N i(110)$ surface caused by oxygen exposure has been found to be independent of the change of the surface conditions, that occurs spontaneously after ion bombardment. A model is suggested in which the observed change in the surface conditions is explained by desorption of argon and oxygen, respectivily. The oxygen concentration in the top layer has been determined using model calculations.

\section{INTRODUCTION}

Low energy ion bombardment, introduced by Farnsworth et al. /1/ for cleaning solid surfaces by sputtering controlled by LEED, is an usual technique nowadays. Side effects at this cleaning procedure are "surface" damage and implanted species, which can be removed by annealing of the crystal /1/. A survey of the aspects of sputtering in surface analys is methods is given by Wehner $/ 2 \%$. Effects caused by ion bombardment studied with ellipsometry have been published by several authors $/ 3-5 /$. In this paper we describe the change of the $\mathrm{Ni}(110)$ surface after termination of the low energy argon ion bombardment. To get insight in this change oxygen exposures have been performed before and after the observed change of the nickel surface. The measurements have been carried out by ellipsometry and Auger electron spectroscopy (AES).

\section{EXPERIMENTAL}

The experiments were performed in a stainless steel UHV system provided with facilities for AES/LEED and ellipsometry, as described elsewhere /6/. The ellipsometric measurements were performed with a PSA rotA ellipsometer at a wavelength of $632.8 \mathrm{~nm}$ by using a He-He laser. The time dependent ellipsometric effects were measured in zone 1 (for zone definition see ref. $/ 7 /$ ) and on-1ine registered. The single crystal was cut by spark erosion from a $5 \mathrm{~N}$ nickel rod (Metal Crystals Ltd.) to within $0.5^{\circ}$ of the (110) orientation. The specimen was mechanicaliy and electrochemically polished and subsequently mounted in the sample holder. The sur face was cleaned by several cycles of argon ion bombardment, oxygen exposure and annealing at $740 \mathrm{~K}$. The ion bombardments were carried out at an argon gas pressure of $5 \times 10^{-5}$ Torr with an ion energy of 600 or $1000 \mathrm{eV}$ and an ion current of about $0.9 \mu \mathrm{A} / \mathrm{cm}^{2}$.

The following successive steps can be distinguished during a measurement cycle: annealing the sample at $740 \mathrm{~K}$ during 30 minutes and cooling down over 3 hours (step 1), ion bombardment (step 2), a time interval in which a change in the surface takes place (step 3), exposition to oxygen (step 4) and ion bombardment (step 5). 
The steps 2,3,4 and 5 were continued until an almost constant value of the ellipsometric parameter $\Delta$ was reached. If the oxygen exposition is performed directly after termination of the bombardment we call this direct exposition, otherwise the term indirect exposition is used.

\section{RESULTS AND DISCUSSION}

The ellipsometric parameter $\Delta$ shows an increase, while the change in $\psi$ can be disregarded during step 2. The averaged maximum change in $\Delta$, reached with in 1.5 hours, appeared to be $0.18^{\circ}$ with a standard deviation of $\pm 0.06^{\circ}$ over 25 cycles. Within the experimental error one could not distinguish between bombardments with ions of 600 or $1000 \mathrm{eV}$. Auger measurements show the removal of oxygen and a sma 11 amount of implanted argon. This probe gives no information about the presence of oxygen into the crystal, because the inelastic mean free path (IMFP) of $515 \mathrm{eV}$ Auger electrons is about $10 \AA / 8 /$.

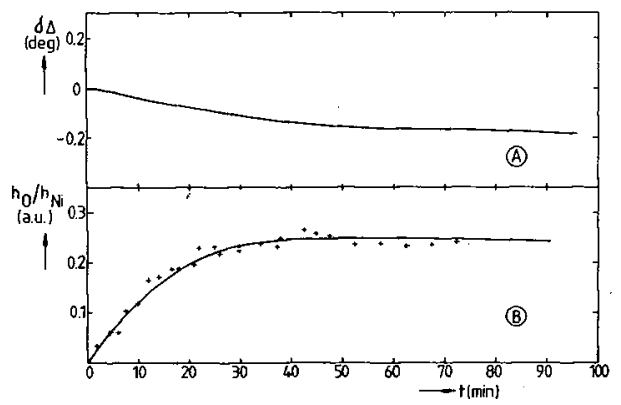

Fig. 1 - The normalized oxygen Auger peak height $\left(\mathrm{h}_{0,515} \mathrm{ev} / \mathrm{h}_{\mathrm{Ni}, 851 \mathrm{eV}}\right)$ (B) and the change in the ellipsometric parameter $\Delta$ (A) during step 3 .

The Auger and ellipsometer signal recorded during step 3 are given in Fig. 1 . The different times in which these signals reach their saturation values can be explained by the difference in IMFP of 515 Auger electrons compared with the penetration depth of the ligth ( $\sim 250 \AA$ for nickel, $K=1.83$ ). The change in $\Delta$ could, besides by the increase of the amount of oxygen, be caused by the desorption of the implanted argon and the rearrangement of the damaged top layer of the crystal. Because the penetration depth of the low energy ions at grazing incidence is in the order of a few layers, implanted argon desorbs easily /9/. It is known that the damage to metal crystal surfaces caused by noble gas ion bombardment is partly annealed out at room temperature $12 \%$. The change in $\Delta$ during step 4 is given in Fig. 2. An important part of the curves for direct and indirect exposition overlaps each other. The experimental error in $\delta \Delta$ is $\pm 0.03^{\circ}$, however, it increases to a maximum of about $-0.1^{\circ}$ in the region between 15 and $40 \mathrm{~L}$. The parameter $\psi$ diminished by 0.08 $\pm 0.2^{\circ}$ to a constant value during the first $20 \mathrm{~L}$ oxygen exposition.

The interaction of oxygen with nickel surfaces has been investigated by many authors using different surface techniques as LEED, RHEED, AES, EELS, X-ray emission, XPS, UPS and RBS. Our ellipsometric investigations will be published in detail elsewhere. The oxidation of the nickel surface takes place in two stages: a non-activated chemisorption stage followed by a nucleation of an oxide displaying a saturation coverage, cf. Mitche11 et al. /10/. The transition of the two stages can be seen also in Fig. 2., it takes place in the interval where the slope of the curve changes temporarily (at about $5 \mathrm{~L}$ ).

Because the transition of the two stages coincides for direct and indirect exposition it can be concluded that the amount of oxygen measured at the end of step 3 is present in a different way than at oxygen exposition. It suggests that the observed oxygen increase takes place by diffusion of oxygen from the bulk to 


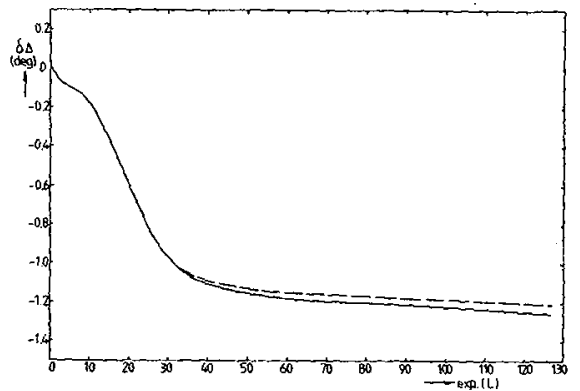

Fig. 2 - The ellinsometric effect in $\Delta$ upon oxygen exposition at $2.5 \times 10^{-7}$ Torr. The continuous and dashed 7 ines represert direct and indirect exposition respectively.

just below the surface. Summarizing, we assume, at the start of step 3 a small amount of oxygen in the bulk of the crystal and a top layer containing implanted argon. During this step the argon desorbs and a new top layer has been created, containing oxygen probably originating from the bulk.

The ellipsometric parameters of the beginning and end of step 3 have been calculated, assuming layers of constant composition, with Mccrackin's program /11/. The applied refractive indices, $n_{1}$, of the the top layers have been derived by substituting the Lorentz-Lorenz equation /12/, given by:

$$
\frac{\tilde{n}_{i}^{2}-1}{\tilde{n}_{i}^{2}+2}=\frac{4 \pi}{3} \frac{\tilde{\alpha}_{i}}{v} \text {, }
$$

where $\tilde{\alpha}_{j}$ is the polarizability of the argon or oxygen atom and $v$ the volume per substrate atom (for nickel 10.9 83 ), in the Maxwel1 Garnett equation /13, 4/ given by:

$$
\frac{\tilde{n}_{1}^{2}-1}{n_{1}^{2}+2}=\frac{\tilde{n}_{2}^{2}-1}{n_{2}^{2}+2}+f \frac{\tilde{n}_{i}^{2}-1}{n_{i}^{2}+2} .
$$

Here $f$ gives the number of argon or oxygen atoms per substrate atom and $\tilde{n}_{2}$ and $\tilde{n}_{j}$ are the refractive indices of respectively nickel (2.29-i4.19, our measurement) and argon or oxygen. Although the published values for the polarizability of oxygen and argon atoms are real $\left(0,79 \AA^{3} / 14 /\right.$ and $1.6 \AA^{3} / 15 \%$, respectively), we have also performed calculations for complex values, given by $\tilde{\alpha}=\alpha^{\prime}+i \alpha "$. Free oxygen argon don't absorb the light, however, the interaction of nickel with interstitial species could cause absorption. The results for these calculations are given in Figs. 3 and 4 as a function of the top layer thickness d for different values of $f$ and $\alpha "$.

Quantitative data of the top layers can be determined on the basis of the assumed model by comparing the measured changes in $\Delta$ and $\psi\left(-0.18^{\circ}\right.$ and $\left.0.00^{\circ}\right)$ with the results in Figs. 3 and 4. A rather good agreement is obtained if we assume a top layer with implanted argon with a thickness of $10 \AA$ where $f=0.05$ and $\alpha^{\prime \prime}=0: 5$, which changes into a top layer with interstitial oxygen with a thickness of 30 where $f=0.05$ and $\alpha^{\prime \prime}=0$. The corresponding calculated ellipsometric effects in $\Delta$ and $\psi$ are $-0.14^{\circ}$ and $+0.04^{\circ}$. The annealing effect at room temperature on surface damage during this process has been disregarded.

Analogous calculations have been performed on a model, where the interstitial oxygen atoms penetrate deeper into the crystal under the influence of argon bombardment, while these atoms diffuse back to just below the surface after termination of the bombardement. The calculations, however, give an opposite effect in $\Delta$ as it has been measured. 

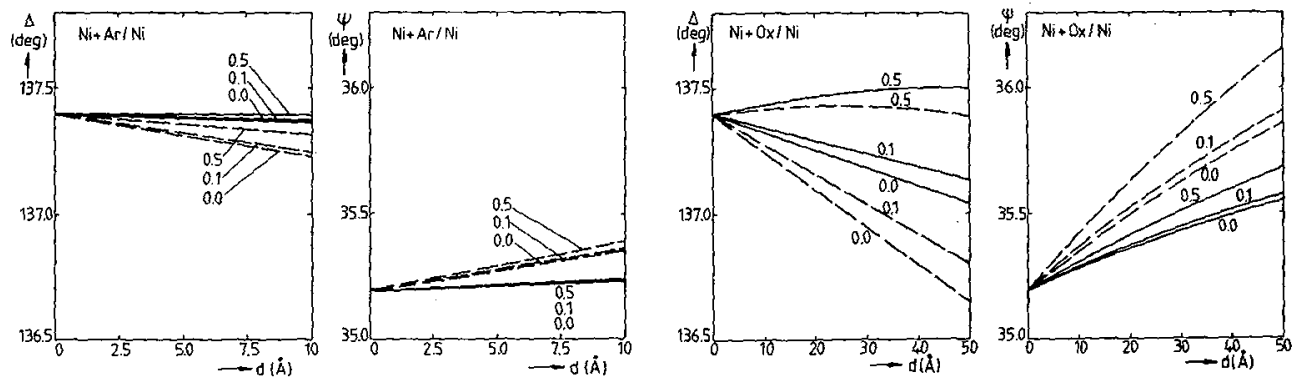

Figs. 3 and 4 - The calculated $\Delta$ and $\psi$ values versus the thickness $d$ of the top layers on nickel, the numbers indicate the value of $\alpha^{\prime \prime}$. The continuous and dashed lines correspond to $f$ equal to 0.01 and 0.05 for nickel with argon, ant to 0.05 and 0.1 for nickel with oxygen.

The thickness of the top layer at the end of step 3 can also be calculated in a different way. We assume the same sputtering yield for this layer as the published value for nickel: 1.45 atoms/ion $/ 2 /$. A dose of about $2 \times 10^{16} \mathrm{ions} / \mathrm{cm}^{2}$ appeared necessary to realize an inverted step 3 by ion bombardment. The calculated thickness of the sputtered layer of the $N i(110)$ surface based on these data is $32 \AA$, which is in a good agreement with the earlier calculated result.

\section{REFERENCES}

1/ FARNSWORTH H.E., SCHLier R.E., GeORGE T.H. and BURGER R.M, J. App 1. Phys. 29 (1958) 1150, 1195.

12/ WEHINER G.K., in: Methodes of Surface Analysis, Ed. A.W. Czanderna (Elsevier, Amsterdam, 1975) p. 5.

13/ VEDAM K., Surface SCi. 56 (1976) 221.

14/ ALBERS H., DROOG G.M.M. and BOOTSMA G.A., Surface Sci 64 (1977) 1.

151 MARTENS J.W.D., BOGERT W.F. VAN DEN, SILFHOUT A. VAN, Surface SCi 105 (1981) 275.

16/ HANEKAMP L.J., LISOWSKI W. and BOOTSMA G.A., Surface Sci. 118 (1982) 1.

17) STRAAYER A., HANEKAMP L.J. and BOOTSMA G.A., Surface Sci. $\overline{96}$ (1980) 217.

18/ SEAH M.P. and DENCH W.A., Surface Interf. Anal. 1 (1979) 2 .

19) CARTER G. and COLLIGON J.S., Ion Bombardment of Solids (Heineman, London, 1968) ch. V.

110/ MITCHELL D.F., SEWELL P.B. and COHEN M., Surface Sci. 69 (1977) 310.

1111 MCCRACKIN F.L., Fortran Program for Analys is of E7\}ipsometer Measurements (Nat). Bur. Std. (US) Tech. Note 479, Washington, DC. 1969).

1121 BOOTSMA G.A. and MEYER F., Surface Sci. 14 (1969) 52.

113/ MAXWELL GARNETT J.C., Phil. Trans. Roy. Soc. (London) 203 (1904) 385, 205 (1906) 237.

14/ BRUNAUUER S., The Adsorption of Gases and Vapour (Univ. Press. Oxford, 1944) p. 189.

115/ AMEY R.L. and COLE R.H., 3. Chem. Phys. 40 (1964) 146. 